phagocytosis of the antigen ${ }^{6,14}$ followed by transfer of cytoplasmic content as RNA or an RNA-antigen complex ${ }^{14}$. The demonstration of a direct cytoplasmic connexion between macrophages and antibody producing cells further established this concept?. Since no change in the RE function was apparent on the removal of the thymus, it is apparent that alterations in phagooytic activity of the RES are not involved in the immunological defects which follow noonatal thymectomy. The possible influence of thymectomy on other motabolic activities of the macrophage system remains to be established.

This work was supported, in part, by a grant from the U.S. A.tomic Energy Commission.

S. H. Monrow N. R. Dr Luzio

Department of Physiology and Biophysies,

University of Tennosseo Medical Units, Memphis.

1 Miller, J. F. A. P., Ann. N.Y. Acad. Sei., 99, 840 (1962).

${ }^{2}$ Martinez, C., Kersey, J., Fapermaster, B. W., and Good, R. A., Proc. Sice. Exp. Biol. and Med., 109, 193 (1962).

${ }^{3}$ Miller, J. F. A. Y., Marshall, A. H. E., and White, K. G., in Advances in Immunology, edit. by Taliaferro, W, II.. and Humphrey, J. H., 2, 111 (Acadtmic Press, New York, 1962).

4 Jankovic, R. D., Waksman, B. H., and Arnason, B. G., J. Exp. Med.,116, $159(1962)$.

${ }^{5}$ Archer, O, Pierce, J. C., Papermaster, B, W., and Good, R. A., Nature, 195, 347 (1962).

"Thorbecke, G. J., and Benacerraf, B., in Progress in Alleryy, edit. by Kallos, P., and Waksman, $\mathrm{H}, \mathrm{H}, \mathrm{6}, 559$ ( $\mathrm{S}$. Karger, New York, 1962).

7 Wooles, W. R., and Di Luzio, N. R., Science, 142, 1078 (1963).

${ }^{y}$ Di Luzio, N. R., and Wooles, W. R., Amer. J. Physiol. (in the press).

Schoenberg, M. D., Mumaw, V. R., Moore, R. D., and Weisberger, A. S. Science, 143, 964 (1963).

${ }^{10}$ Osoba, D., and Miller, J, F, A. P., J. Exp. Med., 119, 177 (1964).

${ }^{31}$ Levey, R. H., 'Trainin, N., and Law, I. W., J. Nat. Cancer Inst., 31, 199 (1963).

${ }^{12}$ Biczzi, G. Benacerraf, B., and Halpern, B. N.. Lrit. J. Exp. Tath., 34 441 (1958).

13 Waksman, B. H, Arnason, B, Q., and Jankovic, 13. D., J. Exp. Med., $\mathbf{1 1 8}, 187$ (1962).

14 Campbell, D. H., and Garvey, J. S., Lab. Invest., 10, 1126 (1961).

\section{Immune Response induced by RNA-Immuno- carrier extracted from Heterologous Immune Sera}

THe importance of nucleoproteing in antibody-globulin production is woll known ${ }^{1,2}$. In previous experiments ${ }^{3,4}$ an ovident increase of the content of RNA in the $\gamma$ globulin fraction in immune sera has beon observed. The RNA extracted from the serum of immunized rabbits is capable of eliciting in normal rabbits the production of antibodies against the same antigens used for immunizing the animals from which this RNA-immuno-carrier (RNA-I-C) was taken. The following investigations wero undertakon to ascertain whother an RNA-I-C extracted from the serum of immunized animals of one specios was ablo to induce antibody production in animals of a differont species.

Young male rabbits were immunized by 6-8 intravonous injections of red blood colls (RBC) of rat or guinea-pig. Tho RNA-I-C extracted ${ }^{2}$ from sora of rabbits immunized with guinon-pig $\mathrm{RBC}$ was introduced into normal rats; normal guinea-pigs woro treated with RNA-I-C obtained from sera of rabbits immunizod with rat $R B C$. The amount of RNA introduced in each nnimal of both groups, by a single intracardiae injection, was $0.28 \mathrm{mg} / 100 \mathrm{~g}$

Tablo 1. IMMUNE RESPONE OF RATS TREATED WITH RNA FROM ANTITREATES WITH RNA FHOM ANTI-RAT HBO HYPERIMMONE RABBIT SHHA Guinea-pig RBC Rats Greated with antiRats treated with antipig RBC RNA Rat RBB
Guinca-pigs treated with antirat RBC LNA

$\begin{array}{ccccc}\text { Controls } & 0 & 0 & 0 & 0 \\ 24 \mathrm{~h} & 1: 80 & 1: 80 & 1: 80 & 1: 40 \\ 48 \mathrm{~h} & 1: 320 & 1: 160 & 1: 320 & 1: 80 \\ 72 \mathrm{~h} & 1: 80 & 1: 80 & 1: 40 & 1: 20 \\ 06 \mathrm{~h} & \text { neg. } & \text { neg. } & \text { neg. } & \text { neg. }\end{array}$

* Negative is legs than 10.

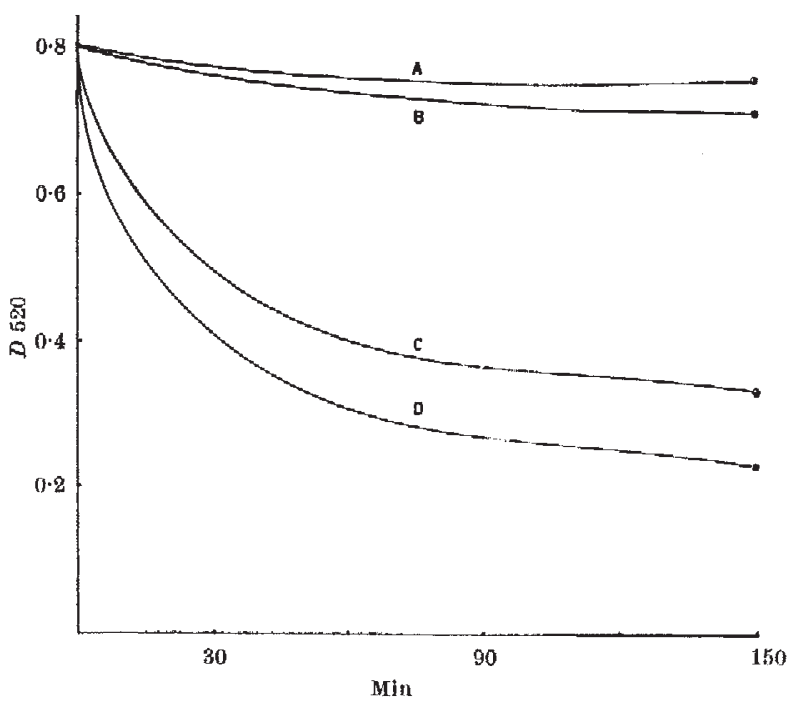

Fig. 1. Spectrophotometric behaviour of rat $\mathrm{RBC}$ or guinea-jig $\mathrm{RBC}$ hamolysis by: $A$, normal rat serum; $B$, normal guinea-pig serum; $C$, serum from rat $48 \mathrm{~h}$ after injection of anti-guinea-pig RBC RNA;
serum from guinea-pig $48 \mathrm{~h}$ after injection of anti-rat $\mathrm{RBC} \mathrm{RNA}$

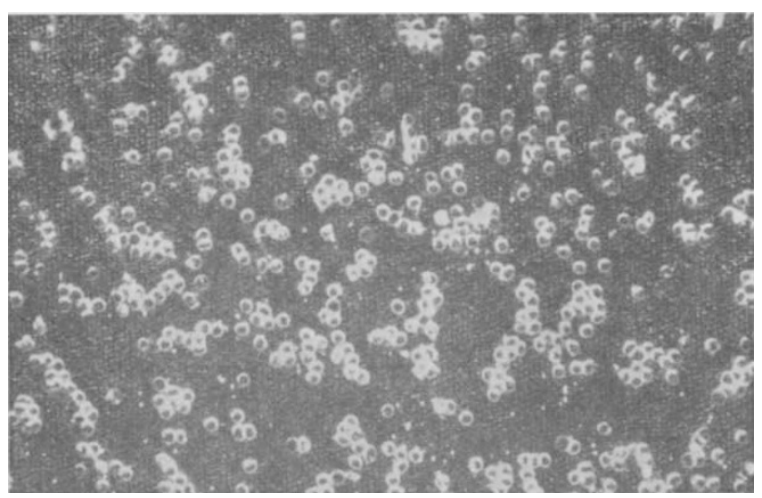

Fig. 2. Immunofluorescence test: guinea-pig RBC incubated at $37^{\circ} \mathrm{C}$ with serum ( $1:$ 10) from rat $48 \mathrm{~h}$ after injection of $\mathrm{KNA}$ - I-C from rabbit globulins

body-weight. At intervals of $24,48,72$ and $96 \mathrm{~h}$ after RNA injection, blood sarnples were collectod and the sor't were subjected to hxmagglutination tests and macroscopic and spectrophotometric ${ }^{4}$ hæmolysis tests.

The results of hremagglutinations and hremolysis are summarized in Table 1. The kinotic behaviour of hæmolysis observed spectrophotometrically is shown in Fig. 1. The antigen-antibody reaction was also shown by the indirect immunofluorescent tochnique (Fig. 2). Check tests of RNA preparations were made by spectrophotomotry in ultrn-violet light.

The data confirm the possibility of eliciting an immune rosponse by RNA-I-C extracted from the serum of immunized animals of a different species.

This investigation was supported by grants from C.N.R., Rome, and from the Ministero dolla Pubblica Istruzione, Italy.

L. Michelazzi

I. BAIDINT

A. Novelat

Institute of General Pathology,

G. NanNI

University of Genoa, Italy.

' Michelazzi, L., Eoll. Ist. Sier. Mil.,29, 28 (1950).

'Fighmun, M., and Adler, F، L., J, Exp, Med.,117, 595 (1903).

${ }^{3}$ Michelazzi, L., Nanni, G. and Baldini, I, , Reported to Meeting, Soc. Ital. Biol. Sperim. (Mareh 25, 1004). 4 Michelazzi, T., Nanni, G., Baldini, I., and Novell, A., Experientia, 20,
447 (1964), 